molecule of pyruvate produced, as reactions (1) and (2) require.

Reaction (1) is an apparent reversal of the synthesis of citrate from oxaloacetate and acetate, catalysed by extracts from Esch. coli ${ }^{10}$. This view is not supported, however, by our results ${ }^{3}$ with whole cells, which indicate that the enzyme involved is adaptive and is suppressed by growth with aeration; extracts from cells so grown possess only feeble activity. Further, when active extracts were treated with 'Dowex-1' according to the method of Chantrenne and Lipmann ${ }^{11}$ to remove coenzyme A, additions of the latter and of diphosphopyridine nucleotide had no effect on activity. It appears that citric acid may by synthesized by one biochemical route involving acetyl-coenzyme $A$ and may be dissimilated in certain systems by another.

We express our thanks to Mrs. M. Lees and Mr. J. Smillie for their technical assistance, to Mr. R. Noble for a helpful discussion, to the Agricultural Research Council for grants for these laboratories and to the Carnegie Trust for a personal grant to one of us (E. A. D.) for apparatus.

Department of Biochemistry, University of Leeds.

Department of Biochemistry, University of Glasgow. May 7.

1 Deffner, M., and Franke, W., Liebigs Ann., 541, 85 (1939).

2 Brewer, C. R., and Werkman, C. H., Enzymol., 6, 273 (1939).

'Dagley, S., and Dawes, E. A., J. Bact. (in the press).

- Hughes, D. E., Brit. J. Exp. Path., 32, 97 (1951).

- Friedemann, T. E., and Haugen, G., J. Biol. Chem., 147, 415 (1943)

'Stephenson, M., "Bacterial Metabolism", 122 (3rd. edit., London, 1949).

7 Krampitz, L. O., and Werkman, C. H., Biochem. J., 35, 595 (1941)

Dagley, S., Fewster, M. E., and Happold, F. C., J. Bact., 63, 327 (1952).

- Plaut, G. W. E., and Lardy, H. A., J. Biol. Chem., 180, 13 (1949). Veiga Salles, J. B., and Ochoa, S., J. Biol. Chem., 187, 849 (1950) ${ }^{10}$ Ochoa, S., Physiol. Rev., 31, 73 (1951), quoting unpublished work of Stern, J. R., and Örgel, G.

${ }^{11}$ Chantrenne, H., and Lipmann, F., J. Biol. Chem., 187, 757 (1950).

\section{A New Hydroxy-acid in the Peel of Apple Fruits}

DuRING the examination of paper chromatograms of extracts from whole mature Edward VII apples, a faint acid spot appeared which did not correspond in position with any of the usual fruit acids. On chromatograms of extracts of peel tissue only, the unknown acid appeared to be present in an amount approximately one-quarter that of the malic acid present (the chief acid present in the fruit). About half a gram of the unknown acid was isolated in the pure form from peel tissue extracts by means of silica gel chromatography ${ }^{x}$, avoiding contact of the extracts with strongly basic ion-exchange resins during the process ${ }^{2}$. The acid crystallized with difficulty from water as needle-like crystals. Recrystallized from ether it gave a melting point of $94-96^{\circ} \mathrm{C}$. On elementary analysis the acid proved to have a molecular formula corresponding to $\mathrm{C}_{5} \mathrm{H}_{8} \mathrm{O}_{5} \quad(\mathrm{C}=$ $\mathbf{4 1 . 5}, \mathrm{H}=\mathbf{5} .4$ per cent) ; its silver salt had a silver content of 58.5 per cent. The molecular weight (Rast) was found to be 146. The acid gave on analysis 9 per cent ' $\mathrm{OH}$ '; the hydroxyglutaric acids contain 11 .5 per cent ' $O H$ ', but $\beta$-hydroxy-acids tend to lose water when treated with acetic anhydride, which would lead to low results in the determination of ' $\mathrm{OH}$ ' groups. Solutions of the acid gave a positive Denigès test ${ }^{3}$ after oxidation with potassium permanganate. These facts provide the basis for its provisional identification as either $\beta$-OH-glutaric acid or citramalic acid. Further details will be published elsewhere.

\section{A. C. Hulme}

Ditton Laboratory, Food Investigation Organization,

Department of Scientific and Industrial Research, East Malling, Maidstone, Kent. April 9.

I Hulme, A. C., J. Exp. Bot., 2, 298 (1951).

${ }^{2}$ Philltps, J. D., and Pollard, A., Nature, 171, 41 (1953). Hulme, A. C. Nature, 171, 610 (1953).

${ }^{3}$ Denigès, M. G., Bull. Soc. Chim. de Paris, (3), 27, 13 (1902).

\section{Purines in Grassland Herbage}

THE non-protein nitrogenous fraction of grassland herbage usually represents $15-20$ per cent of the total nitrogen of the herbage. Since the fraction is frequently blamed, without supporting evidence, for causing ill-defined disturbances in animal health, it is obviously desirable to learn as much as possible about its constituents.

It is known that ammonia, nitrate, acid amides and amino-acids account for 50-60 per cent of the nitrogen of the fraction and their determination presents no difficulties; but the remainder has not been investigated in detail.

The fraction is receiving attention at Jealott's Hill using methods of paper and ion-exchange chromatography. A purine fraction has been separated which contains a mixture of several purines. Four purines have been identified almost certainly as adenine, guanine, xanthine and hypoxanthine, although the latter is not invariably present.

In most of the work herbage juice has been used, removing chloroplastis, protein, etc., by heat and alcohol treatments. The passage of the clarified juice through Zeo-Karb 215, followed by displacement of the bases by alkali, resulted in material coming out of solution in the column and this upset the regularity of displacement. Tests suggested that the insoluble material consisted of purines, and in subsequent work purines were removed from the clarified juice by precipitation with ammoniacal silver nitrate.

The purine fraction, after precipitation of silver with hydrochloric acid, was examined by paper chromatography. The paper when viewed in ultraviolet light (260 $\mathrm{m \mu}$ ) showed four spots which corresponded with the positions of pure adenine, guanine, xanthine and hypoxanthine. So far, it has not been possible to elute the spots and determine the quantities of the individual purines by ultraviolet absorption since the salts and foreign matter present cause tailing of the spots.

Further purification and separation have been effected by passing the solution of purines, in $2 \mathrm{~N}$ acid, through a Zeo-Karb 216 column and eluting with $2 N$ acid. Examination by ultra-violet absorption of the fractions collected showed the presence of the four purines; but considerable overlapping occurred. Using the fractions showing greatest absorption, absorption curves and maxima were obtained which correspond closely with those quoted by Cavalieri et al. ${ }^{1}$ for the purines mentioned above.

If the purines could be eluted separately from an acid resin column, their quantitative determination 